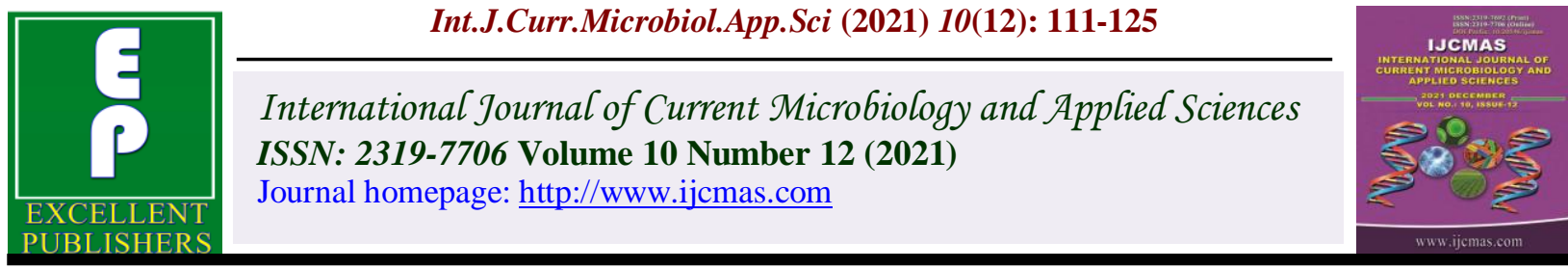

Original Research Article

https://doi.org/10.20546/ijcmas.2021.1012.012

\title{
Sucker Selection on Banana (Musa AAA cv Valery) Root Content, Nematode Populations, and Yield
}

\author{
César Chávez $^{1}$, Luis Calderón ${ }^{2}$, Franco Espinosa ${ }^{2}$, Eduardo Salas ${ }^{3}$ and Mario Araya ${ }^{4 *}$ \\ ${ }^{1}$ Nemalab, Ecuador, \\ ${ }^{2}$ Finca La Paz, El Guabo, Ecuador, \\ ${ }^{3}$ Catedrático Universidad Nacional, Escuela de Ciencias Agrarias, Costa Rica \\ ${ }^{4}$ AMVAC Chemical Corporation, Costa Rica \\ *Corresponding author
}

\section{Keywords \\ Banana, \\ Helicotylenchus \\ spp., Musa AAA, \\ nematodes, \\ Radopholus similis, \\ roots, sucker \\ selection, yield \\ Article Info \\ Received: \\ 05 November 2021 \\ Accepted: \\ 30 November 2021 \\ Available Online: \\ 10 December 2021}

\section{A B S T R A C T}

A field experiment was carried out in El Guabo, Ecuador, to study how sucker selection affect root content, nematode numbers, and yield variables on banana (Musa AAA cv. Valery) plants. The two treatments evaluated were sword sucker selection at plant flowering and early sword sucker selection of $60 \mathrm{~cm}$ height on un-shooting plants. The two treatments were laid out in RCD with ten replicates and in each replicated, 10 of each sucker were evaluated across five ratoon crop cycles. With few exceptions, no differences were found in root contents between the two types of sword sucker selected. No differences in the number of Pratylenchus spp. (P>0.0911), Meloidogyne spp.(P> 0.1011), Helicotylenches spp., ( $\mathrm{P}>0.1189)$, Radopholus similis $(\mathrm{P}>0.2657)$, and total nematodes $(\mathrm{P}>$ 0.0557 ) were found in none of the ratoons between the two types of suckers selected. The number of total nematodes varied across the five ratoon crop cycles between 6021 and 22327 per $100 \mathrm{~g}$ of roots by sucker. In none of the yield variables (bunch weight $\mathrm{P}>0.1528$, ratio $\mathrm{P}>0.1527$, rationing $\mathrm{P}>0.1261$, and number of boxes per hectare by year $P>0.1447$ ) differences were found between the selected suckers at the parent plant and the subsequent four ratoon crop cycles. Across the five harvests, the number of boxes oscillated between 2971 and 4072 per hectare per year. Although, no differences in yield were found, in the last three ratoon crop cycles consistently more than 100 (106 to 133) boxes per hectare per year were got when sucker selection was done on un-shooting plants. Considering the actual market price of a box of $18.14 \mathrm{~kg}$ of bananas of US $\$ 6.25$, the additional net income from the increase in yield, deducted the cost of labour of $\$ 0.75$ of packing for each additional box would varies between 580 to 732 US\$ per hectare per year. 


\section{Introduction}

Bananas (Musa AAA cv. Grande Naine, Valery, and Williams) are cultivated in Ecuador for export markets. It is the most important crop, accounting for almost $25 \%$ of the agricultural gross national product. In 2020, 380.4 million boxes of $18,14 \mathrm{~kg}$ were exported (ACORBANEC, 2021), produced on 176000 (El Universo, 2021a), which gave a total income of US \$3669 million FOB (Moreno et al., 2021).

Although banana is an annual crop, it is produced in a perennial monoculture. To keep the long-term banana ratoon plantation with high productivity, each stool must consist of the mother plant, the follower sucker and when possible, a small peeper. However, in each stool several suckers (usually three) from the underground stem are produced during the banana life cycle which, if allowed to grow freely, can result in intra-mat competition through creation of multiple sinks and intensification of root and corm-rhizome competition for space, water, and nutrients. Even, the follower sucker reduces the bunch weight of the parent plant (Araya and Vargas, 2002). Therefore, growth of excess suckers must be discouraged before they become too large and unmanageable to interfere with growth of the parent plant and the follower sucker, which otherwise will result in extended crop cycle (loss ratooning) and reduced ratoon crop yield (Robinson, 2003; Robinson and Galán, 2010). Ratooning, which is the number of bunches harvested by each banana stool by year influence yield greatly as has been shown by Jaramillo et al., (2019) and Chávez et al., (2020).

Sucker trimming or sucker pruning (removing unwanted or surplus suckers) is one of the most critical operations and controversial issue in banana production and plantation management among growers. When and how to do the sucker selection it is always a question with uncertain answered among growers and technicians. In Ecuadorian banana conditions, some growers do the follower sucker selection, at flower emergence of the parent plant, more likely, following Stover and Simmonds (1987) recommendation. Other growers, remove the surplus suckers on un-shooting plants selecting sword suckers with a range of height usually $60-100 \mathrm{~cm}$ and eliminating the rest.

For the decision on what plant stage to do the sucker selection it is necessary to consider that between the mother plant and its suckers exists translocation of nutrients (Wamsley and Twyford, 1968, Teisson, 1970, Kurien et al., 1999, Kurien et al., 2002, 2006). For MartínPrevel (1964) and Lahav and Turner (1989), this movement of nutrients is important in the nutrition of the follower sucker. In Australia, unwanted suckers must be cut off at an early stage with less of $30 \mathrm{~cm}$ high, otherwise if removal it is carried out late, bunch weight in the parent crop can be reduced by up to $18 \%$ (Tropical banana information kit, 1998).

Robinson and Nel (1990) found a reduction in yield as the height of the unwanted suckers increases in the cv. Williams. According to Kurien et al., (1999) the decrease is a consequence of the continuous transfer of nutrients from the parent plant to the suckers, a process that, although it ceases in the follower sucker with its independence from the mother plant, continues again in the remaining suckers not eliminated.

Independently at which plant stage is done the sucker selection, removing of unwanted suckers, in Ecuadorian conditions, is carried out every 6 to 8 weeks throughout the year, in long-term commercial banana plantations, due to the continuous soil humidity since irrigation is applied during the dry season and semiwarm or warm conditions all the year around. 
With the actual increment in production costs, there is a great need to keep the banana ratoon productivity through improvement of the present standards of husbandry practices since many growers lack the correct scientific bases of de-suckering. The present study was carried out to compare root content, nematode numbers, and yield variables (bunch weight, ratio, ratooning, follower sucker height, boxes per hectare per year) on sucker selection at plant flowering vs early de-suckering, doing the sword follower sucker selection at $60 \mathrm{~cm}$ height in un-shooting plants.

\section{Materials and Methods}

The field experiment was carried out for the parent plant and four consecutive ratoon crop cycles within a long-term (26 years) commercial banana (Musa AAA cv. Valery) plantation located in El Guabo county, province of El Oro, Ecuador. The soil was alluvial, taxonomically classified as an Inceptisol and it had a clay texture $(20 \%$ sand, $20 \%$ silt and $60 \%$ clay) with a $\mathrm{pH}$ of 6.7 and $1.58 \%$ organic matter. The following concentrations of extractable bases were found, using Modified Olsen as the extractant: $\mathrm{Ca} 15.4, \mathrm{Mg} \mathrm{4.7}$, and $\mathrm{K} 0.85 \mathrm{cmol} \mathrm{L}^{-1}$, and $\mathrm{P}$ 33, $\mathrm{Zn} \mathrm{17.2,} \mathrm{Cu} 4.8, \mathrm{Fe}$ 61.0, and Mn $18.9 \mu \mathrm{g}$ $\mathrm{ml}^{-1}$. The block where the experiment was established had an average production in 2016 of 3200 boxes of $18.14 \mathrm{~kg}$ per hectare per year with a plant density of about 1450 plants by hectare.

Before, set up the experiment, de-suckering was carried out every 6-8 weeks in recently flowered plants, leaving the production unit with a bearing mother plant, a large daughter sucker (follower) and a small peeper when possible. Bunching plants were propped with double polypropylene twine to the bottom of two well-developed adjacent plants. The follower sucker of each production unit was fertilized every 28 days at the rate of $80 \mathrm{~kg} \mathrm{ha}^{-}$ ${ }^{1}$ with a formula adapted to the soil and crop requirements, consisting of urea $(46 \% \mathrm{~N})$. Generally, during the rainy season, from January to May each year, water requirements was supplied by rainfall, where the annual precipitation was of 637, 771, 504, and 597 $\mathrm{mm}$ per year, for 2016, 2017, 2018, and 2019, respectively. A complex system of primary, secondary, and tertiary drains was provided to disperse excess rainfall and prevent water logging during heavy rains. From June to December each year, water was supplied by sprinkling irrigation. Mean daily average, maximum, and minimum temperatures were 24.8-29.6-22.3 /25.1-30.1-22.5 / 24.9-30-22.5 and $24.7-29.7-22.3^{\circ} \mathrm{C}$, at the year 2016, 2017 , 2018, and 2019, respectively.

Cultural practices in the experimental site: Leaf fungi, especially black Sigatoka (Pseudocercospora fijiensis), was managed by deleafing weekly to reduce the pressure of black Sigatoka inoculum and by aerial spraying of alternate fungicides which resulted in 31 sprayings each year at 11 to 13 days intervals. The sequencing of the fungicides applied were: 2-3 cycles with Thalonex® 720SC (chloratalonyl-Crystal Chemical) $3 \mathrm{~L}$ $\mathrm{ha}^{-1}$ in water, and then one cycle of Mancozin® 430SC (mancozeb-Crystal Chemical) $2.4 \mathrm{~L} \mathrm{ha}^{-1}$ in combination with Acord ${ }^{\circledR} \quad 250 \mathrm{EC}$ (difeconazole-Crystal Chemical) $0.7 \mathrm{~L} \mathrm{ha}^{-1}$ in emulsion with miscible oil (Banole®-Total) and water, both cases in a spray solution of $23 \mathrm{~L} \mathrm{ha}^{-1}$. Weeds were controlled spraying every 5-8 weeks a Glifonox ${ }^{\circledR} \quad 480 \mathrm{CS}$ (glyphosate-Crystal Chemical) solution of $2 \mathrm{~L}$ in $200 \mathrm{~L}$ of water. Nematodes were controlled every year by 1.5 1.8 nematicide cycles (Counter ${ }^{\circledR}$ 15GRAMVAC, Rugby® 10GR-FMC, Vydate ${ }^{\circledR}$ 24SL-DuPont) per year, based on the nematode economic threshold.

Two treatments were evaluated: treatment 1 , where the follower sucker (sword sucker) selection was done at plant flowering, and treatment 2, where in un-shooting parent 
plants, the follower sucker was selected at 60 $\mathrm{cm}$ height. In both treatments the selected sucker was on the most open side of the parent to keep the distance among stools as equal as possible, to maintain the symmetry arrangement for the plantation. The two treatments were applied randomly to 10 plants each, in 10 contiguous terraces-repetitions (rectangular plots with 150 to 175 stools) within the block. Surplus suckers were removed by cutting off at ground level with a sharp knife. Plots were arranged in a randomized complete design. So, each desuckering type was applied to 100 plants. In each terrace, plants from plot edges, edge drains, cable edges, dompings, replanting plants or from stools with double ratoon suckers, were excluded from treatment.

Just after sucker selection, a root sample for nematode extraction was taken from each sucker. In front of each selected follower sucker, a hole of $20 \mathrm{~cm}$ length, $20 \mathrm{~cm}$ wide and $30 \mathrm{~cm}$ depth (soil volume of $12 \mathrm{~L}$ ) was dug at the plant base using a shovel. All the roots found were collected and placed in labeled plastic bags and delivered to NEMALAB laboratory in coolers for nematode extraction. In the laboratory, the root samples were registered and processed as soon as possible, and when it was necessary, stored in a refrigerator Indurama serie RS$10989-593$ adjusted to $6-8^{\circ} \mathrm{C}$ until being processed. The roots were rinsed free of soil, separated in living roots (white or creamcolored roots), dead roots by nematodes (with symptoms of nematode damage, with light necrosis, but without root decay) and dead roots by other causes (rotten roots by excess water, snapping), left to dry off the surface moisture and weighed (Fisher Scientific serie 10309201 scale precision $710 \mathrm{~g} \pm 1 \mathrm{~g}$ ). During the root separation process, in some roots, it was necessary to cut some damaged parts, which were classified accordingly. The total root weight corresponds to the sum of living roots, dead roots by nematodes and roots dead by other causes.

The three types of roots were cut into $1-2 \mathrm{~cm}$ long pieces separately and after homogenization, $25 \mathrm{~g}$ were randomly selected following the found proportion of each type of root. For example, in a sample of $43 \mathrm{~g}$ of total roots, with $31 \mathrm{~g}$ of living roots, $8 \mathrm{~g}$ of dead roots by nematodes, and $4 \mathrm{~g}$ of dead roots by other causes, there would be $72.1 \%$ of living roots, $18.6 \%$ of dead roots by nematodes, and $9.3 \%$ of dead roots by other causes that multiplied by the used sample size of $25 \mathrm{~g}$, would have $18 \mathrm{~g}$ of living roots, $4.6 \mathrm{~g}$ of dead roots by nematodes and $2.4 \mathrm{~g}$ of dead roots by others causes in the $25 \mathrm{~g}$ sample. These roots were macerated (Araya, 2002) in a kitchen blender (Osterizer; Sunbeam-Oster) for two periods of 10 seconds, at low and then at high speed, and nematode recovered in $0.025 \mathrm{~mm}$ (No 500) sieve. The nematodes were identified at the genus and species level, when possible, based on the morphological characteristics under a light microscope, following the key of Siddiqi (2000). The population densities of all plant-parasitic root nematodes present were recorded, and the values were converted to numbers per $100 \mathrm{~g}$ of roots.

Harvesting of the parent plant and the selected suckers was done by calibration starting when bunches reached 10 weeks of age. When in the second hand, the central fruit of the outer whorl had a diameter of at least a grade of 45 (35.5 mm-diameter) the bunch was harvested. If in week 13, it did not reach the required minimum grade of 45 , they were harvested with the grade they had. Bunch weight (TruTest electronic scale XR3000 kg $\pm 1 \mathrm{~g}$ ), follower sucker height $(\mathrm{m})$ measured from the sucker base to the point of junction of the upper two youngest leaves, were recorder. The ratio, which is the number of boxes of 18.14 $\mathrm{kg}$ given by each bunch, was calculated 
considering a reduction of $20 \%$, because was the average of the farm during the experimental time, which includes $11 \%$ of bunch stalk and $9 \%$ of non-marketable fruit. With the data of the number of bunches harvested in 2016 in the block where the experiment was located, and the number of plants per hectare, the initial ratoon was calculated in 1.63. Since the date of bunch harvest was registered for the 5 ratoon crop cycles in each stool, the ratooning in each ratoon crop cycle was calculated dividing the 365 days of the year by the number of days between bunch harvest in each stool for each of the following crop cycles. The first harvest corresponds to the mother-parent of the selected follower suckers and the others are from the treatment effect.

The composition of the nematode population was determined for each ratoon crop cycle. Data of root weights were averaged for the 10 suckers in each repetition (terrace) and subjected to ANOVA by Proc GLM of SAS. The number of nematodes were averaged for the 10 suckers in each repetition (terrace) and were analyzed with generalized linear models, using the log transformation as link function and negative binomial distribution of the errors. Bunch weight, follower sucker height, ratio, ratooning, and number of boxes of 18.14 kg per hectare per year ( $97 \%$ bunch recovery; 1,406 bunches $*$ ratio $*$ ratooning) were averaged for each repetition (terrace) and ratoon crop and subjected to ANOVA in PCSAS ${ }^{\circledR}$ version 9.4.

\section{Results and Discussion}

With exception of the first ratoon crop cycle, where suckers selected in un-shooting plants, with $60 \mathrm{~cm}$ height had $65 \%$ more $(\mathrm{P}=0.0013)$ living roots than the suckers selected at plant flowering, no differences $(\mathrm{P}>0.1862)$ in living root content were found in the subsequent 4 ratoon crop cycles (Figure 1A). Across the five ratoon crop cycles, living roots in suckers selected at plant flowering varied between 14.8 and $38.7 \mathrm{~g}$ by sucker and in the suckers selected at $60 \mathrm{~cm}$ height it oscillated between 16.2 and $46.9 \mathrm{~g}$ by sucker.

Dead roots by nematodes fluctuated between 2.2 and $8.6 \mathrm{~g}$ by sucker, when it was selected at plant flowering, and between 3.7 and $9.6 \mathrm{~g}$ by sucker when selected at $60 \mathrm{~cm}$ height in un-shooting plants through the five ratoon crop cycles (Figure 1B). Difference (P= 0.0089 ) in dead root by nematodes was only found at the four-ratoon crop cycle, where suckers selected at $60 \mathrm{~cm}$ height, had 68\% (1.5 g) more damaged roots by nematodes.

Dead roots by other causes were very small in both treatments, varying between 0.1 and $1.2 \mathrm{~g}$ by sucker when selected at plant flowering and between 0.3 to $1.5 \mathrm{~g}$ by sucker selected at $60 \mathrm{~cm}$ height (Figure 1C). With exception of the first ratoon crop cycle, where suckers selected at $60 \mathrm{~cm}$ height in un-shooting plants, had $1.2 \mathrm{~g}(500 \%)$ more $(\mathrm{P}=0.0008)$ dead roots by other causes than those suckers selected at plant flowering, in the subsequent four ratoon crop cycles no differences $(\mathrm{P}>0.0767$ ) were observed.

The total root weight by sucker (sum of living roots + dead roots by nematodes + dead roots by other causes) across the five ratoon crop cycles oscillated between 21 and $44 \mathrm{~g}$ and between 21 and $58 \mathrm{~g}$ by sucker when selected at plant shooting or at $60 \mathrm{~cm}$ sucker height in un-shooting plants, respectively (Figure 1D). Difference in total root weight was observed only in the first ratoon crop cycle, where suckers selected at $60 \mathrm{~cm}$ height in unshooting plants had $21 \mathrm{~g}(56 \%)$ more $(\mathrm{P}=$ 0.0028 ) than those selected at plant flowering. Percentage of living roots by sucker varied across the five ratoon crop cycles between 72 to $89 \%$ in suckers selected at plant flowering and between 74 to $86 \%$ in suckers selected at 
$60 \mathrm{~cm}$ height in un-shooting plants (Figure 1E). With exception of the four-ratoon crop cycle, where suckers selected at plant flowering had $7 \%$ more $(\mathrm{P}=0.0003)$ living roots than the suckers selected at $60 \mathrm{~cm}$ height in un-shooting plants, in the others ratoon crop cycles no differences $(\mathrm{P}>0.1740)$ were found.

The composition of the plant-parasitic nematode population varies slightly across the five ratoon crop cycles (Figure 2A-E). The most abundant nematode was Radopholus similis which varies between 39.9 to $51.5 \%$, followed closely by Helicotylenchus spp. that oscillated between 39.9 and $50.4 \%$, thereafter Meloidogyne spp. which fluctuated between 4.8 and $15.5 \%$ and finally Pratylenchus spp. with a negligible amount between 1.8 and 3\% of the nematode population.

The number of Pratylenchus spp. was small in both type of selected suckers across the five ratoon crop cycles without differences $(\mathrm{P}>$ 0.0911) in none of the ratoons. In suckers selected at flowering the population varied between 73 and 424 and in suckers selected at $60 \mathrm{~cm}$ height in un-shooting plants between 167 and 448 per $100 \mathrm{~g}$ of roots per sucker (Figure 3A). The population of Meloidogyne spp. was similar ( $\mathrm{P}>0.1011)$ in both types of suckers across the five ratoon crop cycles (Figure 3B). It varied in suckers selected at plant flowering between 388 and 1145 and in suckers selected at $60 \mathrm{~cm}$ height in unshooting plants, between 456 and 988 per 100 $\mathrm{g}$ of roots per sucker.

Helicotylenchus spp. per $100 \mathrm{~g}$ of roots per sucker was similar ( $\mathrm{P}>0.1189)$ for both type of suckers, across the five ratoon crop cycles (Figure 3C). The number fluctuated between 2410 and 9491 and between 2733 and 12401 per $100 \mathrm{~g}$ of roots for suckers selected at plant flowering and suckers selected at $60 \mathrm{~cm}$ height in un-shooting plants, respectively. For $R$. similis, the population for both type of suckers, was similar (P> 0.2657) across the five ratoon crop cycles (Figure 3D). The number varied between 2698 and 10067 and between 2280 and 8538 per $100 \mathrm{~g}$ of roots in suckers selected at plant flowering and in suckers of $60 \mathrm{~cm}$ height in un-shooting plants, respectively. Also, no differences $(\mathrm{P}>0.0557)$ between the two kinds of suckers selected were found across the five ratoon crop cycles for total nematodes (Figure 3E). The population in the suckers selected at plant flowering varied between 6021 and 21127 and in the suckers selected at $60 \mathrm{~cm}$ height in unshooting plants, oscillated between 6206 and 22327 individuals per $100 \mathrm{~g}$ of roots per sucker, respectively.

In bunch weight, no differences ( $\mathrm{P}>0.1528$ ) were found for the two suckers selected for the parent plant and across the fourth subsequent ratoon crop cycles (Figure 4A). For the suckers selected at plant flowering, bunch weight varied between 31.7 and $36.6 \mathrm{~kg}$, and for those selected at $60 \mathrm{~cm}$ height in unshooting plants, it fluctuated between 34.9 and $36.4 \mathrm{~kg}$ per bunch. With exception of the second ratoon crop cycle, where the follower sucker height at harvest of the parent plant from those de-suckered when the follower sucker reached $60 \mathrm{~cm}$ height in un-shooting plants, which were $21 \mathrm{~cm}(7.8 \%)$ taller, in the others ratoon crops, no differences (P> 0.1981 ) were found (Figure 4B). The follower sucker height varied between 262 and $290 \mathrm{~cm}$, and between 254 and $296 \mathrm{~cm}$ in those selected at plant flowering and those selected at $60 \mathrm{~cm}$ height in un-shooting plants.

Ratio, which is the number of banana fruit boxes $(18.14 \mathrm{~kg})$ obtained from each bunch, was similar (P> 0.1527) between the two selected suckers for the parent plant and across the four ratoon crop cycles (Figure 4C). In suckers selected at plant flowering it varied between 1.40 and 1.63 and for those selected at $60 \mathrm{~cm}$ height in un-shooting plants it 
fluctuated between 1.41 and 1.77 boxes per bunch. Ratooning, which is the number of bunches harvested per year in each banana stool was similar $(\mathrm{P}>0.1261)$ for both types of selected suckers across the four ratoon crop cycles (Figure 4D). In stool de-suckered at plant flowering, the ratooning varied between 1.51 and 1.79 and in those where the sucker was selected at $60 \mathrm{~cm}$ height in un-shooting plants, it fluctuated between 1.60 and 1.85 bunches per stool per year. No differences (P> $0.1447)$ in the number of boxes of $18.14 \mathrm{~kg}$ per hectare per year (1450 plant density * 97\% bunch recovery $=1406$ bunches $*$ ratio $*$ ratooning) between the two kinds of selected suckers was found for the parent plant and across the subsequent four ratoon crop cycles (Figure 4E). For suckers selected at plant flowering, it varied between 2971 and 3752 and for suckers selected at $60 \mathrm{~cm}$ height in unshooting plants, it oscillated between 3104 and 4072 boxes per hectare per year.

In root variables (living roots, root dead by other causes, total root weight) most of the differences found where in the first ratoon crop cycle, which it is reasonable, because the suckers evaluated at that time did not have the treatment effect. That evaluation was done when the experiment starts, on a commercial banana plantation where de-suckering was carried out at plant flowering. Therefore, the differences found on root variables are obvious, since de-suckering on un-shooting plants was done at specific sucker height of 60 $\mathrm{cm}$, while in the sucker trimming at plant flowering, the sucker selected was the sword sucker regardless of its height, which means that those suckers were old, taller and had more roots.

The abundance of $R$. similis (between 39.9 and $51.5 \%$ ) and Helicotylenchus spp. (between 39.9 and 50.4\%) agreed with Jaramillo et al.,
(2019) who reported 31.5 and $68.2 \%$ and Chávez et al., (2020) who found 44.6 and $42.1 \%$ of $R$. similis and Helicotylenchus spp., respectively, in Ecuadorian conditions. High proportion of Helicotylenchus spp. have been reported in Ecuador in banana plantations with insufficient nematode control (Jaramillo et al., 2019). A similar behaved have been found in Costa Rica (Araya and Moens, 2005), and Belize (Salguero et al., 2016), where high proportions of Helicotylenchus spp. was found in areas with insufficient nematode control. However, the farm where the experiment was run, managed nematode with almost two nematicide cycles per year for the last 10 years. Then, more likely, the saline soil conditions present, favored Helicotylenchus abundances since this nematode was found associated with the decline of banana plantations in Israel (Minz et al., 1960) where soils are also saline.

The population of the four nematode genera found were similar in both types of suckers selected across the five ratoon crop cycles. This was expected and it is reasonable since the suckers selected where in the same terrace, with equal soil and weather conditions, and with exception of sucker selection, the same farm management practices. The experimental area was within a long-term commercial banana plantation that have been infected with nematodes for long time.

In the follower sucker height, only in the second ratoon crop cycle, suckers selected at $60 \mathrm{~cm}$ height on un-shooting plants were taller than those selected at plant flowering. This faster growth should be related with the time of the year on which the selection was done. It is known that from December to May, temperatures and radiation are close to the optimum and frequent in the zone where the experiment was run. 
Fig.1A-E Fresh root weight (g) of living roots (A), dead roots by nematodes (B), dead roots by other causes (C), total roots (D), and percentage of living roots in banana (Musa AAA cv. Valery) suckers selected at plant flowering or at $60 \mathrm{~cm}$ height in un-shooting plants across five ratoon crop cycles. Each bar is the average of ten repetitions. In each repetition, 10 follower suckers were evaluated, and a hole of $20 \mathrm{~cm}$ long, $20 \mathrm{~cm}$ wide, and $30 \mathrm{~cm}$ dept was dug at the base and in front of the follower suckers.
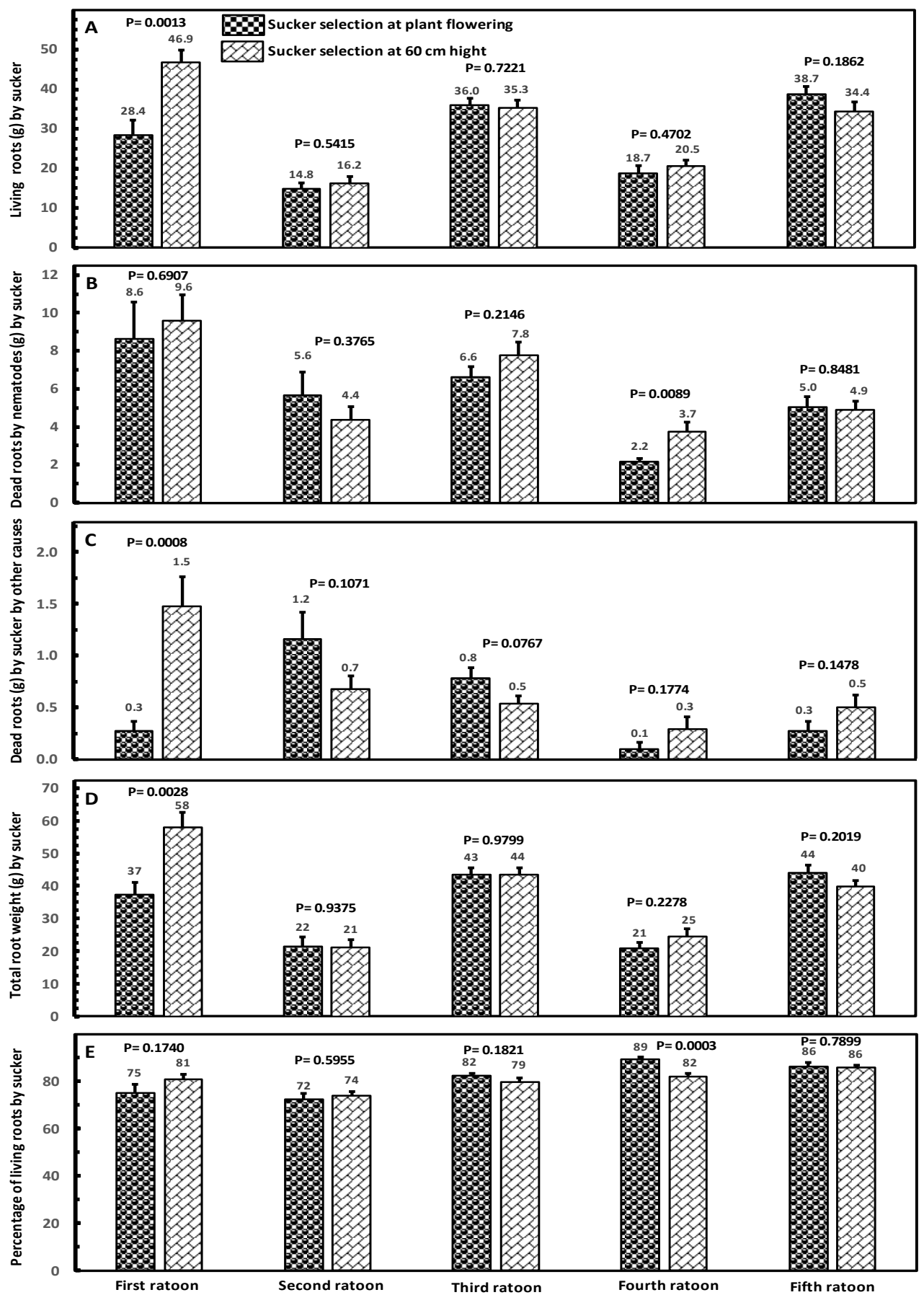
Fig.2 Proportion from the nematode population of each plant parasitic nematode genus in banana (Musa AAA cv. Valery) sucker roots by ratoon crop cycle. Each slide is the average of ten repetitions. In each repetition, 10 follower suckers selected at plant flowering and at $60 \mathrm{~cm}$ height in un-shooting plants, were sampled digging a hole of $20 \mathrm{~cm}$ long 20 , cm wide, and $30 \mathrm{~cm}$ dept at the base and in front of them, and all roots were collected for nematode extraction.

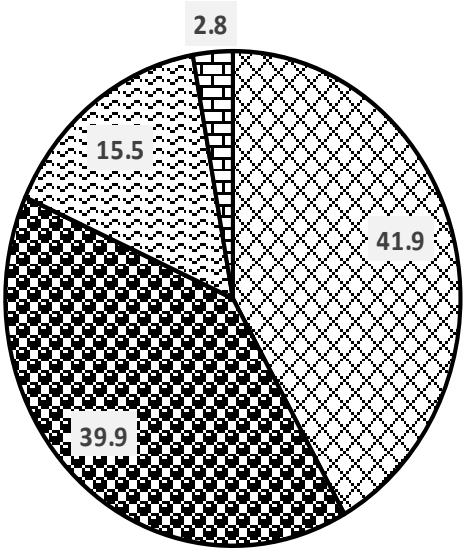

Ratoon crop cycle 1

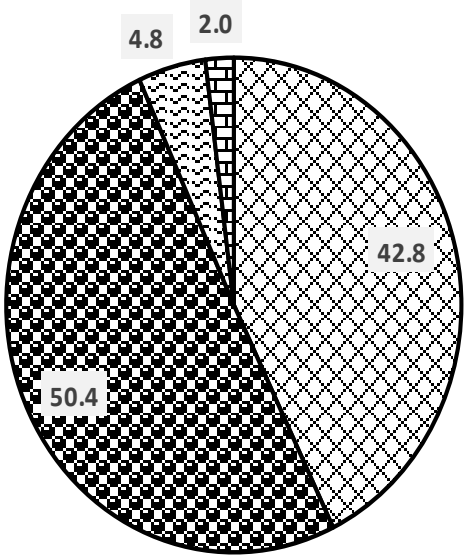

Ratoon crop cycle 2

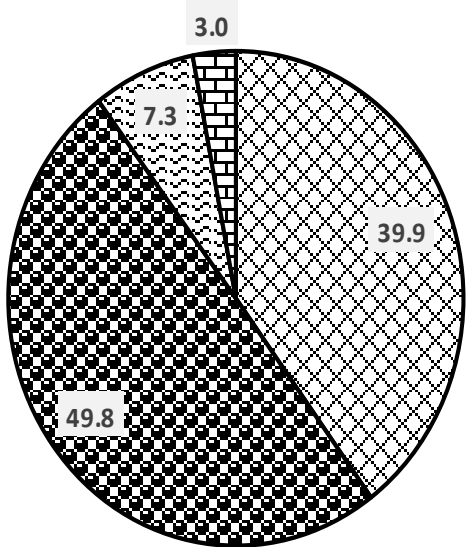

Ratoon crop cycle 3

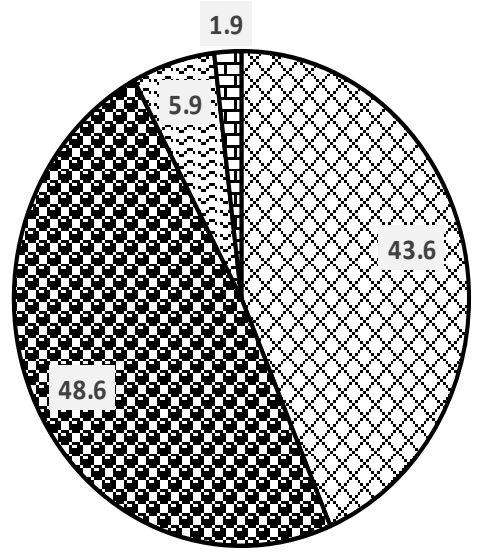

Ratoon crop cycle 4

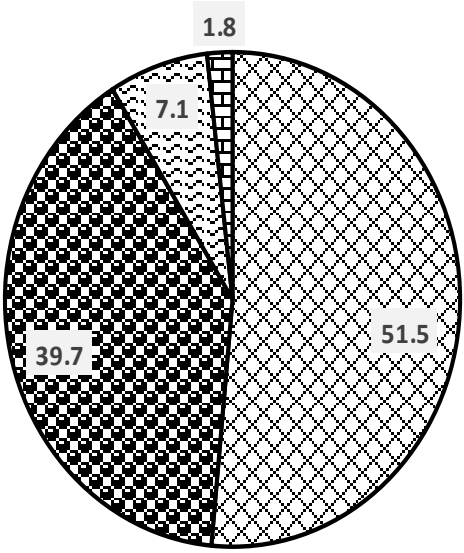

Ratoon crop cycle 5
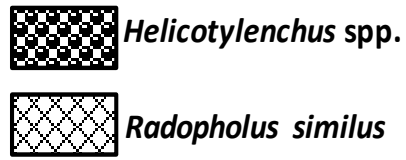

Meloidogyne spp.

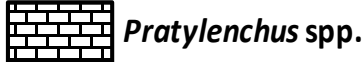


Fig.3A-D Number of Pratylenchus spp. (A), Meloidogyne spp. (B), Helicotylenchus spp., Radopholus similis (D), and total nematodes (E) per $100 \mathrm{~g}$ of banana (Musa AAA cv. Valery) roots by sucker selected at plant flowering or at $60 \mathrm{~cm}$ height in un-shooting plants across five ratoon crop cycles. Each bar is the average of ten repetitions. In each repetition, 10 follower suckers were sampled digging a hole of $20 \mathrm{~cm}$ long, $20 \mathrm{~cm}$ wide, and $30 \mathrm{~cm}$ dept at the base and in front of them, and all roots were collected for nematode extraction.
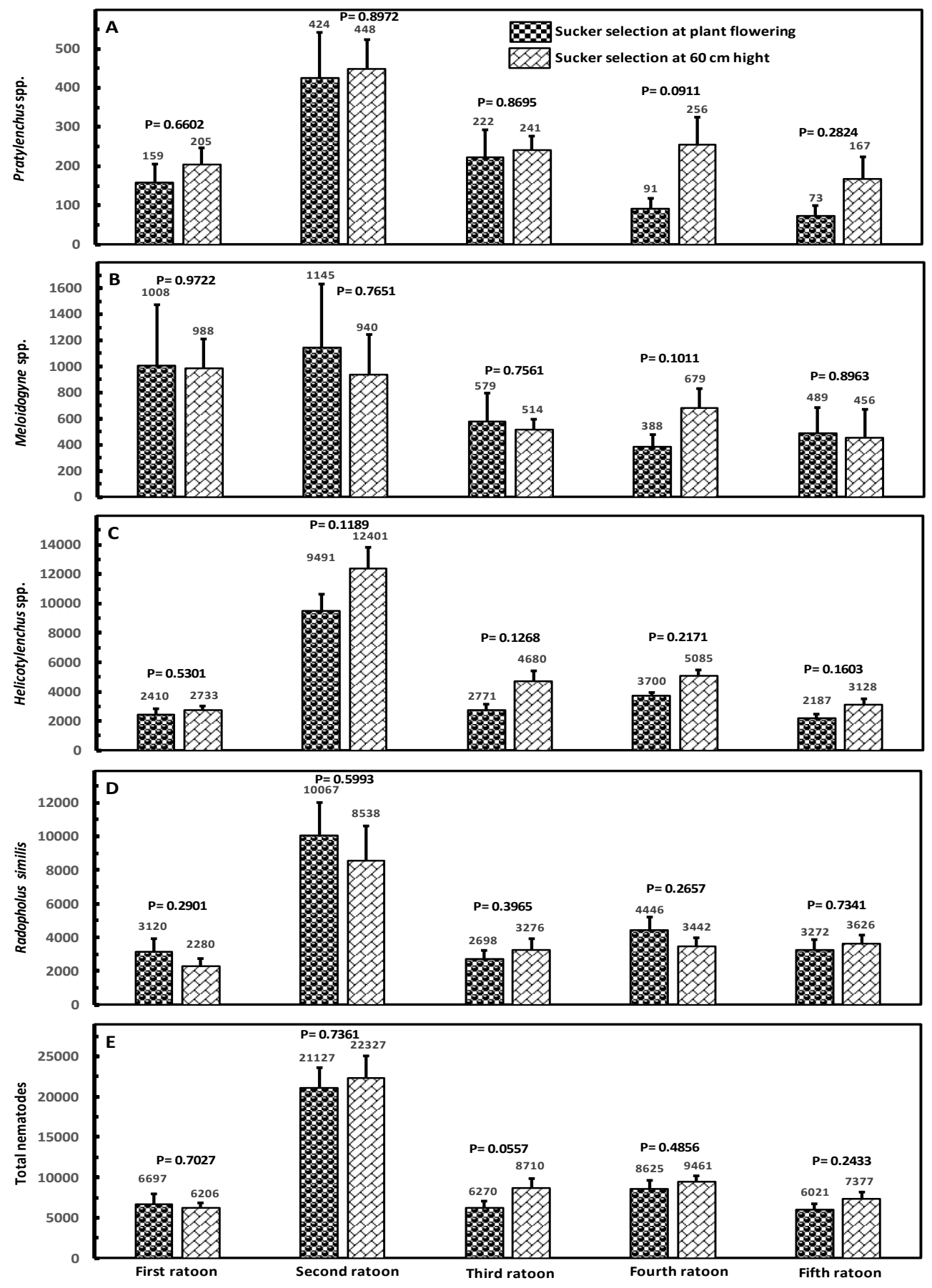
Fig.4A-E A) Bunch weight $(\mathrm{kg}), \mathrm{B})$ follower sucker height $(\mathrm{cm}), \mathrm{C})$ ratio (number of banana boxes of $18.14 \mathrm{~kg}$ per bunch), D) ratooning (number of bunches harvested by stool by year), E) number of boxes per hectare per year by sucker selected at plant flowering or at $60 \mathrm{~cm}$ height in un-shooting plants in the parent plant and across fourth ratoon crop cycles. Each bar is the average of ten repetitions and in each repetition 10 follower suckers were evaluated.
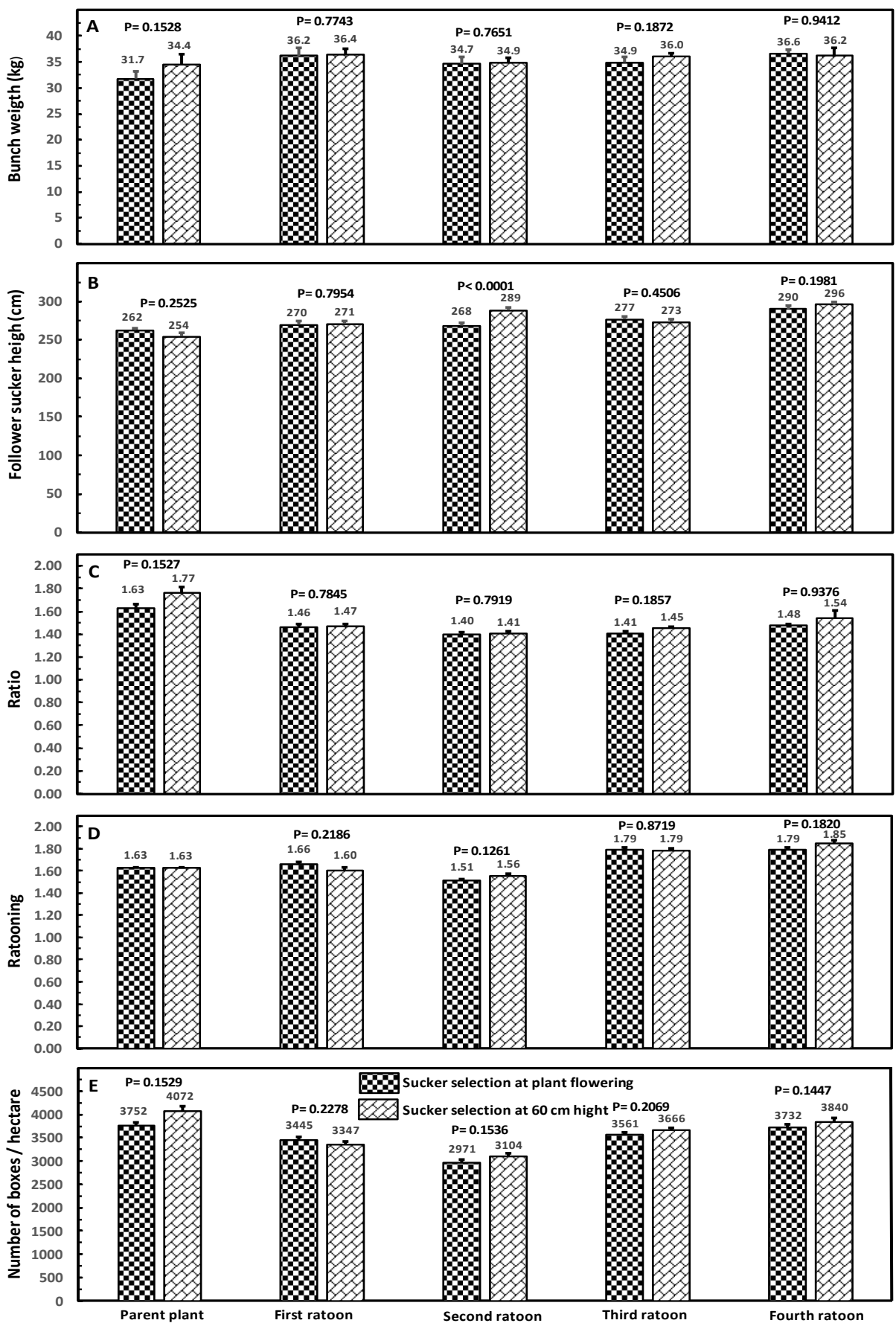
None of the yield variables (bunch weight, ratio, ratooning or number of boxes per hectare per year) evaluated was affected by the type of sucker selected at the parent plant and across the four ratoon crop cycles. Our results contrast with those of Raouf (2008) who reported increased vegetative growth, yield, shortest growth cycles and time to harvest, when unwanted suckers were removed at 15 and $20 \mathrm{~cm}$ height compared with suckers of 30, 40 and $100 \mathrm{~cm}$ height in the hot arid climate of Sudan. Also disagreed with Gasim et al., (2014), who found as well in Sudam, that early de-suckering $(15 \mathrm{~cm}$ and $20 \mathrm{~cm}$ ) gave better plant height, pseudostem girth and total number of functional leaves than delayed de-suckering (30, 40 and $100 \mathrm{~cm}$ height). In South Africa, Robinson and Nel (1990) determined experimentally, that by allowing all excess suckers in a Williams plantation to reach a height of 50 or $80 \mathrm{~cm}$ before removal, average yield per annum after three cycles was decreased by 7.6 and $15.6 \%$ respectively, compared with the recommended $30 \mathrm{~cm}$ for de-suckering. However, it is necessary to keep in mind, that those differences were found within farm production systems developed in subtropical conditions.

In Costa Rica, tropical conditions, Soto et al., (1992), Soto (2015) considered that unwanted suckers should be eliminated after they reach at least $60 \mathrm{~cm}$ height, while Stover and Simmonds (1987) recommended, also in tropical conditions to do the sucker selection at plant shooting, removing those with at least $1 \mathrm{~m}$ tall. Suckers with this height still have the leaves in the thin, bract like stage which does not compete with the selected follower sucker, while suckers with broad leaves, rapidly become competitive with the selected follower sucker. In tropical conditions, removing of undesired suckers must be done frequently between 4 and 8 weeks, not allowing them to become excessively large and unmanageable. For example, in Jamaica (Dadzie, 1999), in fields over 3 years old, recommend setting of followers during the routine pruning operation which it is carried out every 6-8 weeks. However, the frequency of de-suckering varies with the climate and labour costs. For example, In South Africa, monthly desuckering it is recommended in summer, but it is unnecessary in winter (Robinson 2003). In Puerto Rico, de-suckering is carried out when labour it is available and at high cost.

Unwanted large suckers deplete the nutrient reserves of the stool, reduce transmission of radiation, cause a drain of assimilates from the parent plant, compete directly with follower sucker, extending the crop cycle and reducing the yield (Robinson and Galán, 2010, Robinson, 2003). Borah et al., (2018) found on banana cv. Malbhog (AAB) in the state of Assam India, that mother plants +1 sucker/plant recorded higher yield (19.73 $\mathrm{t} / \mathrm{ha}$ ), shorter period from harvesting of first crop to harvesting of first ratoon crop (72.92 days) compared with 2, 3 and 4 suckers per plant.

Even though, in both treatments, the unwanted young suckers were cut off at ground level leaving the meristem undamaged, the sucker regrows was so small $(<15 \mathrm{~cm})$ that did not need cutting again in none of the ratoon crop cycles. One advantage of this way of desuckering, is the prevention of spreading soilborne diseases and nematodes since the tool did not get in contact with the soil. In addition, they give anchorage to the stool without drain assimilates from the parent plant.

The results obtained suggest that in tropical conditions, the selection of suckers must be made considering additional attributes of the de-suckering method because no differences in yield were found. Nevertheless, in the last three ratoon crop cycles consistently more than 100 (106 to 133) boxes per hectare per year were got when sucker selection was done 
on un-shooting plants. Considering the actual market price of a box of $18.14 \mathrm{~kg}$ of bananas of US \$6.25 (El Universo, 2021b), the additional net income from the increase in yield, deducted the cost of labour of $\$ 0.75$ of packing for each additional box would varies between US\$ 580 to 732 per hectare per year, since all the other cultural practices were the same for both types of sucker selection. For those who prefer to do the sucker selection at plant flowering in Ecuadorian conditions, the unwanted suckers to be removed still have the leaves in the thin, bract like stage. Then, in parallel with Soto et al., (1992), and Soto (2015) thought, we also believe that this surplus suckers in such stage give vitality and support to the mat due to sucker prolific root system that provides anchorage to the stool. However, we disagreed with them in the contribution of nutrients from the sucker to the mother plant. In contrast, our results are consistent with research that indicates a transfer of nutrients from the mother towards the sucker (Martín-Prevel, 1964; Wamsley and Twyford, 1968; Teisson, 1970; Lahav and Turner, 1992; Kurien et al., 1999, 2002, 2006). In Costa Rica, (Araya and Vargas, 2002) comparing the bunch weight of parent plants with and without the follower sucker, found a higher bunch weight when follower sucker was eliminated at plant shooting, which support the translocation of assimilates from the parent to the follower. Along with the desuckering, it is done the stem desheathing, it is removes the rotten standing pseudostem and the soil surface around the selected sucker it is cleaned.

\section{References}

ACORBANEC (Asociación de Comercialización y Exportación de Banano). (2021).

Análisis de las exportaciones de banano del Ecuador: de enero a diciembre del 2020. 17p. http://www.acorbanec.com
$>$ uploads > 2021/01

Araya, M., Moens, T. (2005). Parasitic nematodes on Musa AAA (Cavendish subgroup, cvs Grande Naine, Valery, and Williams). Pp: 201-223 in Turner, D. W., Rosales, F. E. eds. Banana root system: towards a better understanding for its productive management. Proceedings of an international symposium, INIBAP, Montpellier, France.

Araya, M., Vargas, A. (2002). Efecto de la remoción del hijo de sucesión a la floración sobre el peso del racimo y el contenido foliar de nutrimentos en la planta madre de banano (Musa AAA). CORBANA 28(55):1-12.

Araya, M. (2002). Metodología utilizada en el laboratorio de nematología de Corbana S. A. para la extracción de nematodos de las raíces de banano (Musa AAA) y plátano (Musa AAB). CORBANA 28 (55): 97-110.

Borah, R, Hazarika, D. N., Langthasa, S., Duarah, D. P. (2018). Effect of number of suckers per hill on growth and yield of banana cv Malbhog (AAB) in ratoon crop. International Journal of Current Microbiology and Applied Sciences. 7(10):18121820.https://doi.org/10.20546/ijcmas.2 018.710.207

Chávez, C., Rubio, D., Tobar, M., Salas, E., Araya, M. (2020). Number of nematicide cycles per year on banana (Musa AAA cv Valery) root nematode control and crop yield. International Journal of Science and Research, 9(7):1651-1663. DOI: 10.21275/SR20722023421

Dadzie, B. K. (1999). A guide to banana production in Jamaica. A reference Manual. National Resources institute (Great Britain), Jamaica Banana Board. 198p.

El Universo,(2021a). En un año se legalizaron 
menos de 10.000 hectáreas de banano y plátano sembradas informalmente. https://www.eluniverso.com/noticias/e conomia/en-un-ano-se-legalizaronmenos-de-10000-hectareas-de-bananoy-platano-sembradas-informalmentenota/

El Universo, (2021b). Precio de la caja de banano se mantiene en $\$ 6,25$. https://www.eluniverso.com/noticias/e conomia/precio-de-la-caja-de-bananose-mantiene-en-625-nota/

Gasim, S., Mahdi, E. M., Raouf, A. F. A. (2014). Effects of stage of desuckering on Growth characteristics of banana clone Williams W-193/3. International Journal of Science, Environment and Technology 3(1):357-364.

Jaramillo, J., Vintimilla, M., Rubio, D., Soto, G., Tobar, M., Salas, E., Araya, M. (2019). Effect of nematicide rotation on banana (Musa AAA cv. Williams) root nematode control and crop yield. Agronomía Colombiana 37(2):153165.

DOI:10.15446/agron.colomb.v37n2.79 099

Kurien S., Kumar, P. S., Kamalam, N. V., Wahid, P. A. (2006). Intermat and intramat competition in banana studied using ${ }^{32} \mathrm{P}$. Fruits, 61(4):225-235. DOI: 10.1051/fruits:2006020

Kurien, S., Kumar, S. P., Kamalam, V. N., Wahid, A. P. (2002). Nutrient cycling from the Musa mother plant at various physiological stages to suckers as affected by spacing and sucker retention using tracer techniques. Fruits $\quad 57(3): 143-151$. DOI: 10.1051/fruits:2002013

Kurien, S., Anil, B. K., Kumar, P. S., Wahid, A. P., Kamalam, N. V. (1999). Estudios de nutrientes en el banano utilizando ${ }^{32} \mathrm{P}$. InfoMusa $8(1)$, Noticias de Musa:35-36.

Lahav, E., Turner, D. W. (1989). Banana nutrition. International Potash Institute, Berne/Switzerland. IPI-Bulletin 7. 62p.

Martin-Prevel, P. (1964). Nutrient elements in the banana plant and fruit. Fertilité 22: 3-14.

Minz, G., Ziv, D., Strich-Harari, D. (1960). Decline of banana plantations caused by spiral nematodes, in the Jordan Valey, and its control by DBCP. Ktavin 10:147-157.

Moreno, G. D. A., Vite, C. H., Carvajal, R. H. (2021). Análisis económico sobre los efectos del Covid-19 en las principales exportaciones de los productos no petroleros. Pol. Con. (Edición núm. 62), 6(9):1214-1239.

Raouf, A. A. H. F. A. (2008). Evaluation of William's banana (Musa cavendish L.) clones under hot arid climates of the Sudan. Ph.D. Thesis. University of Khartoum, 276p.

Robinson, J. C., Nel, D. J. (1990). Competitive inhibition of yield potential in a Williams banana plantation due to excessive sucker growth. Scientia Horticulturae. 43:225236.https://doi.org/10.1016/03044238(90)90094-U

Robinson, J. C. (2003). Bananas and plantains. Crop Production Science in Horticulture. CAB International. 238p.

Robinson, J. C., Galán, S. V. (2010). Bananas and plantains. Crop Production Science in Horticulture. $2^{\text {nd }}$ Edition. CAB International. 311p.

Salguero, D., Rudon, G., Blanco, R., Moya, C., Ramclam, W., Medina, L., Azofeifa, D., Araya, M. (2016). Effect of different nematicide applications per year on banana (Musa AAA) root nematode control and crop yield. Journal of Applied Biosciences 101: 9598-9609.

http://dx.doi.org/10.4314/jab.v101i1.4

Siddiqi, M. R. (2000). Tylenchida: parasites of plants and insects. $2^{\text {nd }}$ ed. CABI 
Bioscience, $\mathrm{CAB}$ International, Wallingford, UK. $833 \mathrm{p}$. Doi:10.1079/9780851992020.0000

Soto, B. M. (2015). Bananos II: tecnologías de producción. Editorial Tecnológica de Costa Rica. 704p.

Soto, M., Soto, E., Solis, P., López, A. (1992). Siembra y operaciones de cultivo. In Soto, M. ed. Bananos Cultivo y Comercialización. Second Edition. San José, Costa Rica, Litografía e imprentaLIL. Pp: 211-363.

Stover, R. H., Simmonds, N. W. 1987.
Bananas. Third Edition. Tropical Agriculture Series. Longman Group Limited, UK. 459p.

Teisson, C. (1970). Conduction vers un bananier d'elementsmineraux absorbés par son rejects dubananier. Fruits 25(6):451-454.

Tropical banana information kit, (1998). Queensland Government. 85p.

Walmsley, D., Twyford, I. (1968). The translocation of phosphorus within a stool of Robusta banana. Tropical Agriculture 45(3):229-233.

\section{How to cite this article:}

César Chávez, Luis Calderón, Franco Espinosa, Eduardo Salas and Mario Araya. 2021. Sucker Selection on Banana (Musa AAA cv Valery) Root Content, Nematode Populations, and Yield. Int.J.Curr.Microbiol.App.Sci. 10(12): 111-125. doi: https://doi.org/10.20546/ijcmas.2021.1012.012 